\title{
Ground-Water Flow and Water Quality of the Indian Island Well Field near Grand Island, Nebraska, 1994-95
}

\section{-By Patrick J. Emmons and Phillip R. Bowman}

\section{Introduction}

Ground water is the principal source of water for public and self-supplied domestic use in Nebraska. Ground water supplied about $235 \mathrm{Mgal} / \mathrm{d}$ (million gallons per day) in 1990 , or about 78 percent of the estimated public-water supply in Nebraska. In addition, ground water supplied about $1,017 \mathrm{Mgal} / \mathrm{d}$, or about 83 percent of the irrigation water in the Platte River Valley (Nebraska Natural Resources Commission, 1994). Withdrawing ground water in the valley induces recharge from the river and has the potential to change ground-water quality near the river where many publicsupply wells are located.

The Platte River alluvial aquifer, which underlies the Platte River Valley (fig. 1), is the single most important source of water for public supply in central and eastern Nebraska. The aquifer, which is part of the High Plains aquifer, consists of stream-laid deposits of sand and gravel with discontinuous layers of clay and silt, and is connected hydraulically to the Platte River. The aquifer provides about $117 \mathrm{Mgal} / \mathrm{d}$, or nearly 50 percent of the total daily ground-water production for Nebraska (Nebraska Natural Resources Commission, 1994). The aquifer also supplies water to Nebraska's largest

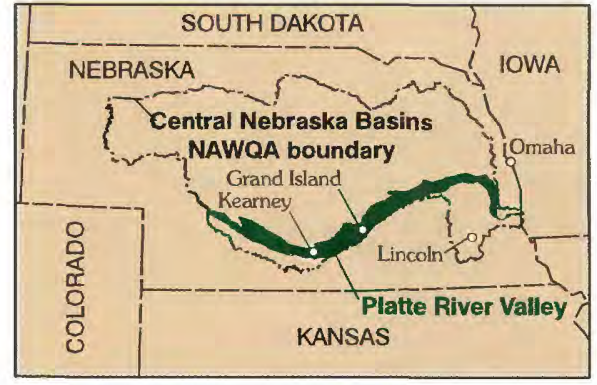

Figure 1. Location of the Central Nebraska Basins area. cities including Kearney, Grand Island, Lincoln, and Omaha.

The U.S. Geological Survey's (USGS) National Water-Quality Assessment (NAWQA) Program is designed to describe the status and trends in the quality of the Nation's surface- and ground-water resources and to provide a sound understanding of the natural and human factors affecting the quality of these resources. Important components of the program are investigations of more than 50 major river basins and aquifers, called study units. The Central Nebraska Basins (CNBR) (fig. 1) was among the set of 20 study-unit investigations begun in 1991. Assessment of the water resources as related to public-water supply is one aspect of the study.

Three locations in the Platte River Valley were studied to assess the effects of water withdrawals on ground-water quality near the Platte River. This fact sheet summarizes the water quality of one location, the City of Grand Island's

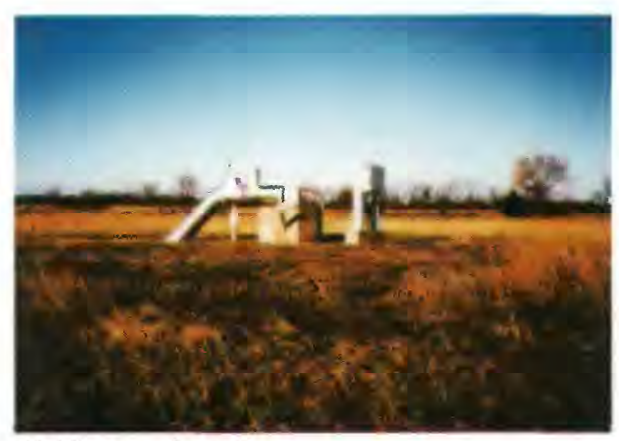

Public-supply well.

Indian Island well field. For a description of the other two studies, the reader is referred to Frenzel and others (1998).

The City of Grand Island, in eastcentral Nebraska, has a population of about 40,000 and lies about 7 miles north of the Platte River (fig. 2). The average water demand in 1995 for the city was about $10 \mathrm{Mgal} / \mathrm{d}$, with a peak demand of about $20 \mathrm{Mgal} / \mathrm{d}$ during the summer (Gary Mader, Utilities Director, City of Grand Island, oral commun., 1997). The city originally obtained all of its publicwater supply from wells located in and near the city that were completed in the

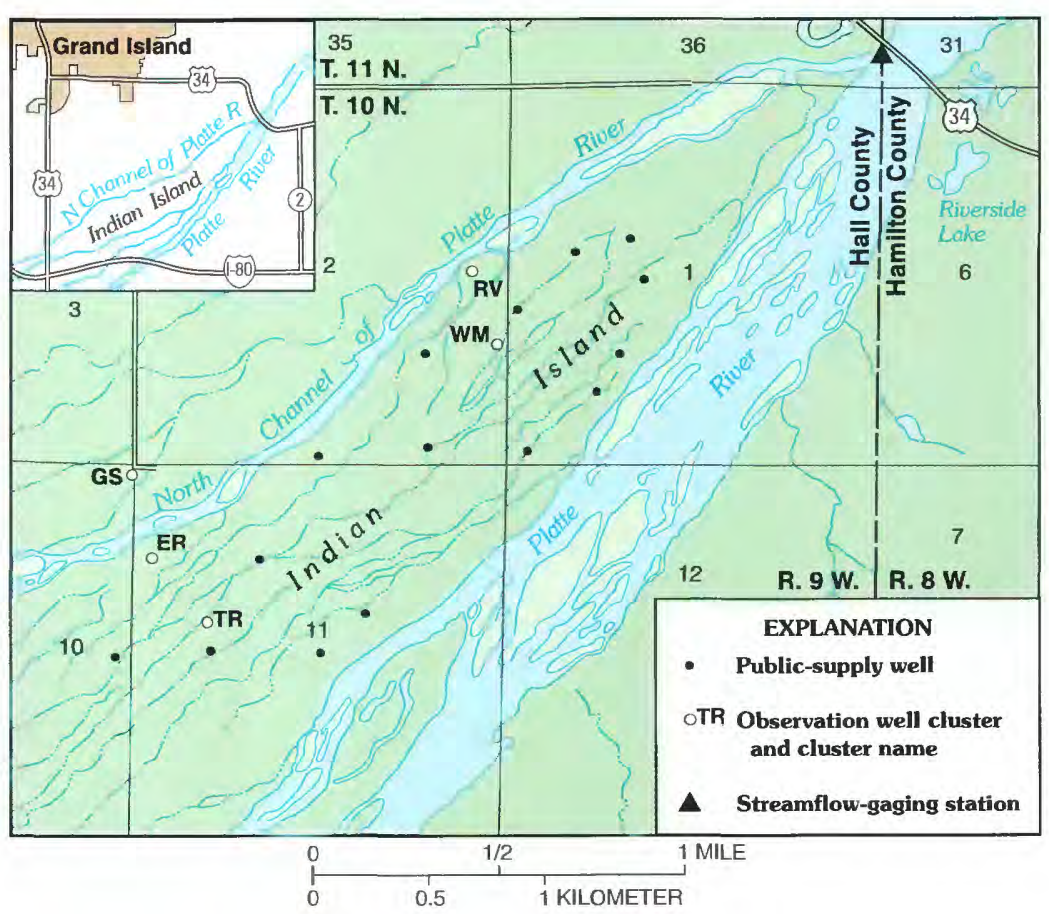

Figure 2. Indian Island well field near Grand Island, Nebraska. 
Platte River alluvial aquifer. In the late 1950 s, concerns about adequate future supplies and the potential for groundwater contamination caused by various land-use practices prompted the city planners to begin looking for additional sources of water.

In 1962, the city began developing the Indian Island well field between channels of the Platte River, southeast of the city. Because the wells are on an island, it is possible that recharge from the river would help avoid potential ground-water contamination of the well field and would provide an additional source of good quality water to the aquifer. In general, the closer a well is to a stream and the higher the pumpage rate of the well, the more the quality of the well water will be influenced by the water quality of the stream. Land use within the well field also is an important factor affecting the potential for ground-water contamination.

The well field is on the eastern half of Indian Island and consists of 15 wells (fig. 2), each capable of yielding up to 1,500 gallons per minute. A typical public water-supply well consists of about $50 \mathrm{ft}$ (feet) of blank casing with an 80 - $\mathrm{ft}$ screened interval at the bottom.

To assess water-quality conditions of the well field, USGS hydrologists installed observation wells in four clusters (ER, TR, RV, and WM) of five wells each along two transects approximately perpendicular to the north channel of the Platte River (fig. 2). An additional cluster (GS) of four observation wells was installed just north of the river. Observation wells on the island are completed at depths of about 20,40,60, 90 , and $125 \mathrm{ft}$. The observation wells north of the river are completed at depths of about 15, 40, 70, and $115 \mathrm{ft}$. All wells have 2.5 -ft screened intervals at the bottom and are open to the Platte River alluvial aquifer.

\section{Ground-Water Flow}

The regional direction of groundwater flow in the alluvium is to the northeast, approximating the general direction of flow along this stretch of the Platte River. Although local water levels routinely fluctuate over short periods of time as a result of pumping of public-supply wells, no long-term water-level changes have occurred in the area (McGuire and Sharpe, 1997). Depth to the water table in the well field varies from 0 to about $10 \mathrm{ft}$. The depth to water in wells and the horizontal component of ground-water flow in the well field are dependent on the pumpage rate of the supply wells, infiltration of precipitation, and the stage of the river. Water levels in observation wells in a cluster can vary depending on the depth of the wells. Naturally occurring vertical differences in water-level altitudes typically are on the order of several tenths of a foot. Pumping-induced waterlevel differences of more than $4 \mathrm{ft}$ were measured between the shallowest and deepest observation wells, reflecting a strong downward vertical component of flow in one cluster in the well field.

\section{Water Quality}

Ground-water quality is affected by dissolution of natural geologic materials and by human activities. Land use in the CNBR is primarily agricultural. Between Grand Island and a short distance northwest of the river, land use is irrigated corn production. In the central Platte Valley, extensive applications of nitrogen fertilizers, pesticides, and irrigation water are made each year to sustain crop yields. In addition, sandy, permeable soil and shallow ground water increase the vulnerability of ground water to the effect of agricultural chemicals (Frenzel and others, 1998). Vegetation grades from a meadow surrounding the well field to predominately cottonwood trees and some junipers near the river.

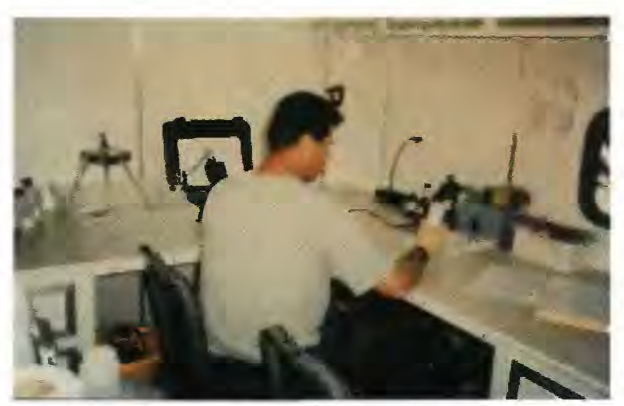

Field preparation of water samples.

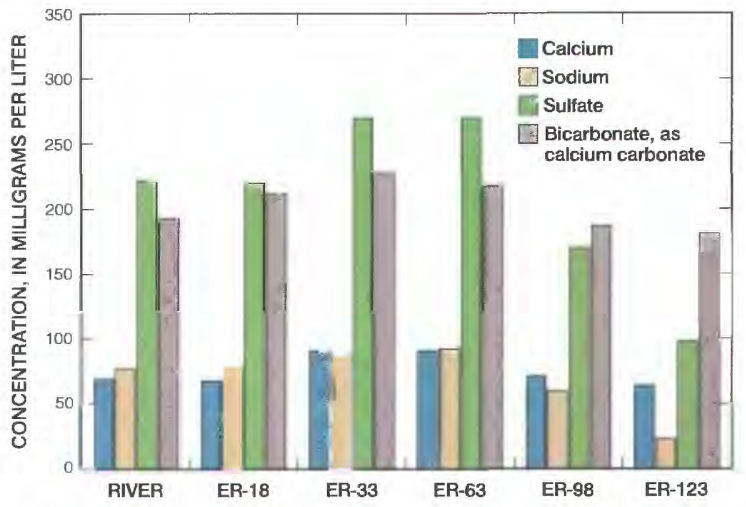

Figure 3. Average major-ion concentrations in water from the Platte River northeast of Indian Island (1993-95) and from wells in cluster ER, August 1995.

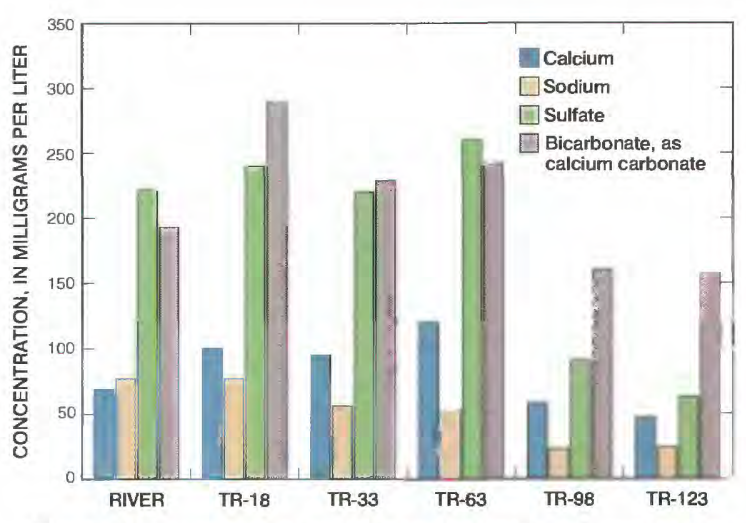

Figure 4. Average major-ion concentrations in water from the Platte River northeast of Indian Island (1993-95) and from wells in cluster TR, August 1995.

Surface-water samples were collected at a streamflow-gaging station northeast of the island near highway 34. Fortyseven ground-water samples were collected for analysis during 1994-95 from wells in the five well clusters. Samples were analyzed for dissolved solids, major ions, hardness, nitrate as nitrogen, and pesticides.

\section{Dissolved Solids}

General water quality typically is described by the dissolved-solids concentration. Evaluating water quality based on dissolved solids or any other constituent is dependent on the use of the water. Concentrations of dissolved solids varied with location and depth of the wells from which samples were collected. Concentrations ranged from 443 to $746 \mathrm{mg} / \mathrm{L}$ (milligrams per liter), with a median concentration of $578 \mathrm{mg} / \mathrm{L}$. The Secondary Maximum Contaminant Level (SMCL) established by the U.S. Environmental Protection 


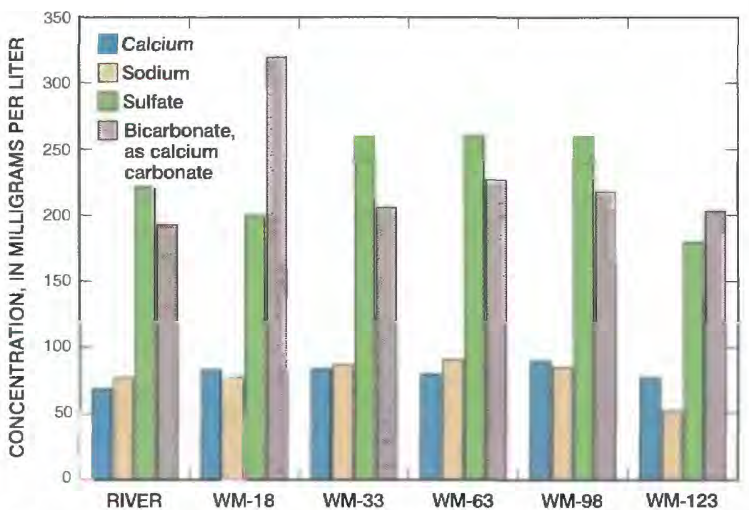

Figure 5. Average major-ion concentrations in water from the Platte River northeast of Indian Island (1993-95) and from wells in cluster WM, September 1995.

Agency (1996) for dissolved solids is $500 \mathrm{mg} / \mathrm{L}$. No Maximum Contaminant Level (MCL) has been established; however, water containing more than $1,000 \mathrm{mg} / \mathrm{L}$ dissolved solids is unsuitable for many purposes (Hem, 1985).

\section{Major lons}

The ionic compositions of the water collected from wells in the well field and the river were dominated by calcium and sodium cations and sulfate and bicarbonate anions (figs. 3. 4, and 5). Essentially, little difference existed in the composition and the concentrations of major ions in samples collected from the well field in comparison to samples from the river. Major-ion composition varied vertically and areally within the Platte River alluvial aquifer in the study area. Major-ion concentrations did not exceed the U.S. Environmental Protection Agency (1996) primary or secondary drinking-water regulations or criteria.

\section{Hardness}

In water, nearly all hardness is due to calcium and magnesium content (Driscoll, 1986). Hard water prevents soap from forming a lather and deposits soap curd on bathtubs. Water with a hardness of $60 \mathrm{mg} / \mathrm{L}$ (as calcium carbonate) or less is considered soft; 61 to $120 \mathrm{mg} / \mathrm{L}$, moderately hard; 121 to $180 \mathrm{mg} / \mathrm{L}$, hard; more than $180 \mathrm{mg} / \mathrm{L}$, very hard (Hem, 1985). Average hardness in samples collected in the well field and from the river ranged from hard to very hard (fig. 6).

\section{Nitrate as Nitrogen}

Nitrate in ground water is a problem in parts of Nebraska and commonly is caused by the leaching of nitrogen fertilizers into the ground water. Drinking water with large concentrations of nitrate has been reported to be the cause of methemoglobinemia (an often fatal disease in infants) (Sawyer and McCarty, 1978. p. 444). Nitrate in surface water also encourages growth of algae and other organisms that produce undesirable tastes and odors (Wetzel, 1983).

Concentrations of nitrate in streams generally were substantially lower than concentrations in shallow ground water in the Platte River Valley (Frenzel and others, 1998). Nitrate concentrations were low in samples collected in the well field, probably a reflection of the minimal land development and pumpageinduced recharge from the river. Frenzel and others (1998) indicated that the median nitrate concentration in samples collected during late 1994 and early 1995 was $1.37 \mathrm{mg} / \mathrm{L}$ as $\mathrm{N}$ (nitrogen), and that nitrate concentrations in samples collected from late August to early September 1995 ranged from less than the detection limit $(0.05 \mathrm{mg} / \mathrm{L}$ as $\mathrm{N})$ to $0.59 \mathrm{mg} / \mathrm{L}$ as $\mathrm{N}$. All concentrations were less than the U.S. Environmental Protection Agency (1996) MCL of $10 \mathrm{mg} / \mathrm{L}$ as $\mathrm{N}$ for drinking water. In a national study conducted by the USGS,

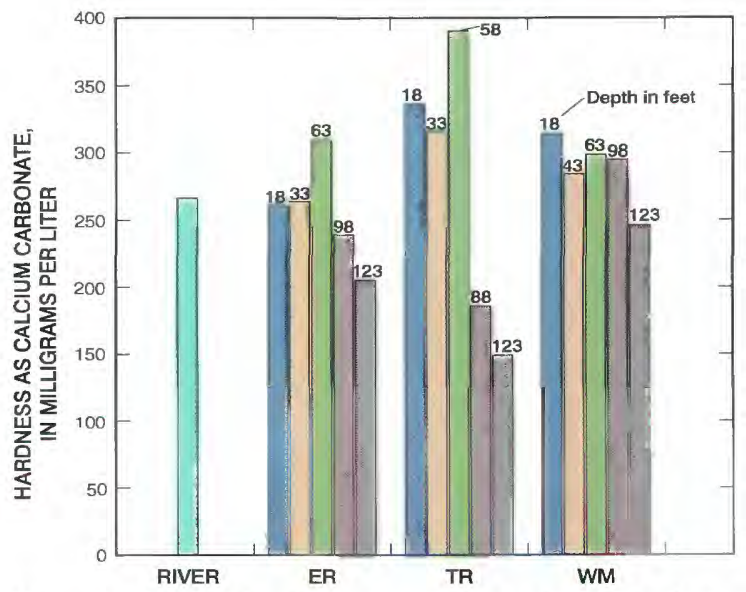

Figure 6. Average hardness in water from the Platte River northeast of Indian Island (1993-95) and from wells in clusters ER (August 1995), TR (August 1995), and WM (September 1995).
Madison and Brunett (1985) found that nitrate concentrations greater than $3.0 \mathrm{mg} / \mathrm{L}$ as $\mathrm{N}$ may be indicative of human-related contributions of nitrate.

\section{Pesticides}

Contamination of surface and ground water from nonpoint sources is a national issue. Of the many possible contaminants, pesticides receive the most attention because of their potential toxicity to aquatic life and humans. Herbicides prevent or inhibit the growth of weeds that compete for nutrients and moisture needed by crops. In addition to the application on crops, herbicides also commonly are used for weed control in urban areas, often with large rates of application.

Forty-seven samples were collected from observation wells between December 1994 and September 1995 and were analyzed for 12 pesticides commonly used in Nebraska. Of the 12 pesticides, only atrazine, prometon, and propazine were detected in measurable concentrations of $0.05 \mu \mathrm{g} / \mathrm{L}$ (micrograms per liter) or higher. Atrazine was detected in wells in all five clusters but in low concentrations. Atrazine was not detected in samples collected from the deepest (about $125 \mathrm{ft}$ ) wells. At the cluster where water levels are the most affected by pumping (TR) (fig. 2), atrazine was detected only in the shallow well. The highest concentration of atrazine detected $(0.38 \mu \mathrm{g} / \mathrm{L})$ was in a sample collected from well WM-63 in September 1995. Between April 1993 and July 1995, concentrations of atrazine in samples collected from the Platte River at the streamflowgaging station ranged from 0.1 to $14.7 \mu \mathrm{g} / \mathrm{L}$, with a median concentration of $0.6 \mu \mathrm{g} / \mathrm{L}$. The MCL for concentrations of atrazine in drinking water, established by the U.S. Environmental Protection Agency (1996), is $3.0 \mu \mathrm{g} / \mathrm{L}$. Prometon was detected in 3 of the 47 samples and propazine was detected in 2 of the 47 samples collected from the five well clusters. Concentrations were substantially less than the health advisory established by the U.S. Environmental Protection Agency (1996) for prometon $(100 \mu \mathrm{g} / \mathrm{L})$ and propazine 
$(10 \mu \mathrm{g} / \mathrm{L})$. The highest concentration of prometon $(0.06 \mu \mathrm{g} / \mathrm{L})$ was detected in a sample from well WM-43, and the highest concentration of propazine $(0.41 \mu \mathrm{g} / \mathrm{L})$ was detected in a sample from well ER-98.

It is probable that the source of pesticides in the ground water is the Platte River, considering no pesticides are applied on the island. The differences in the concentrations detected at different times of the year indicate seasonal variation. During the spring, concentrations of pesticides in midwest rivers are frequently 3 to 10 times greater than the MCL for drinking water (Thurman and others, 1991). Herbicides like atrazine, prometon, and propazine can be transported to streams or rivers by overland flow, through drainage tiles, or by ground water. A potential input of herbicides to the ground water is from precipitation. A study conducted by the USGS during 1990-91 (Stamer and others, 1997) detected measurable concentrations of herbicides (primarily atrazine) in rainfall. Average concentrations of 0.2 to $0.4 \mu \mathrm{g} / \mathrm{L}$ were common during this period. As with concentrations in the Platte River, the occurrence of herbicides in rainfall also varied seasonally. Once contaminants are transported to a stream or river, dynamic surface-water and ground-water interactions affect their storage and further distribution in the environment (Squillace and others, 1996). Alluvial aquifers adjacent to large rivers are particularly vulnerable to these interactions because of bank storage and flooding (Squillace and others, 1996). The seasonal variation of concentrations of pesticides, in conjunction with the similarity of concentrations of the major ions detected in samples collected from the river and from the well field (figs. 3 , 4 , and 5) confirms that the river is hydraulically connected to the ground water in the alluvial aquifer.

\section{Acknowledgments}

The authors thank the City of Grand Island for making data available for this study, and the city and the Goldenrod Girl Scout Council for allowing this study to be conducted on their properties.

\section{Selected References}

Driscoll, F.G., 1986, Groundwater and wells: St. Paul, Minnesota, Johnson Filtration Systems, Inc., p. 90-92.

Exner, M.E., and Spalding, R.F., 1990, Occurrence of pesticides and nitrate in Nebraska ground water: Lincoln, University of Nebraska Water Center, $39 \mathrm{p}$.

Frenzel, S.A., Swanson, R.B., Huntzinger, T.L., Stamer, J.K., Emmons. P.J.. and Zelt, R.B., 1998, Water quality in the Central Nebraska Basins, Nebraska, 1992-95: U.S. Geological Survey Circular 1163, 33 p.

Gosselin, D.C.. Headrick. Jacqueline, Chen, Xun-Hong, Summerside, Scott, Tremblay, Rod, and Bottger, Kurt, 1996, Domestic well-water quality in rural Nebraska: University of NebraskaLincoln and Nebraska Department of Health, various pagination.

Hem, J.D., 1985, Study and interpretation of the chemical characteristics of natural water (3rd ed.): U.S. Geological Survey Water-Supply Paper 2254, 263 p.

Huntzinger, T.L., 1991, National WaterQuality Assessment Program-The Central Nebraska Basins: U.S. Geological Survey Open-File Report 91-97, $2 \mathrm{p}$.

Madison, R.J., and Brunett, J.O., 1985, Overview of the occurrence of nitrate in ground water of the United States, in National water summary 1984-Hydrologic events, selected water-quality trends, and ground-water resources: U.S. Geological Survey Water-Supply Paper 2275, p. 93-105.

McGuire, V.L.. and Sharpe. J.B., 1997. Waterlevel changes in the High Plains aquifer-Predevelopment to 1995: U.S. Geological Survey Water-Resources Investigations Report 97-4081, 2 sheets.

Nebraska Natural Resources Commission, 1994, Estimated water use in Nebraska, 1990: Lincoln, Nebraska Natural Resources Commission, 58 p.

Nguyen, Q.M., and Gilliland, M.W., 1985, A surface water - groundwater interaction model for the Platte River Well Field of the City of Grand Island [Nebraska]: Omaha, University of Nebraska Lincoln. Department of Civil Engineering, $179 \mathrm{p}$.

Pederson, D.T., 1994, Fundamentals of groundwater contamination: University of Nebraska-Lincoln. Conservation and Survey Division, Educational Circular $11,18 \mathrm{p}$.
Sawyer, C.N., and McCarty, P.L., 1978, Chemistry for environmental engineering: New York, McGraw-Hill Book Company, 532 p.

Spalding, R.F., 1975, Effects of land use and river seepage on groundwater quality in Hall County, Nebraska: Nebraska Water Survey Paper No. 38, 95 p.

Squillace, P.J., Caldwell, J.P., Schulmeyer, P.M., and Harvey, C.A., 1996, Movement of agricultural chemicals between surface water and ground water, lower Cedar River Basin, Iowa: U.S. Geological Survey Water-Supply Paper 2448. $59 \mathrm{p}$.

Stamer, J.K., Goolsby, D.A., and Thurman, E.M., 1997, Herbicides in rainfall across the midwestern United States, 1990-91: U.S. Geological Survey Fact Sheet 181-97, 4 p.

Stamer, J.K., and Huntzinger, T.L., 1994, Spring herbicide "flush" may deal cities a problem: Nebraska Farmer, May 1994, v. 136. no. 8 , p. 10-13.

Thurman, E.M., Goolsby, D.A., Meyer, M.T., and Kolpin, D.W., 1991, Herbicides in surface waters of the midwestern United States-The effect of spring flush: Environmental Science and Technology, v. 25 , no. 10 , p. 1794-1796.

U.S. Environmental Protection Agency, 1996, Drinking Water Regulations and Health Advisories: Washington, D.C., U.S. Environmental Protection Agency, Office of Water, $14 \mathrm{p}$.

Wetzel, R.G., 1983, Limnology (2nd ed.): Philadelphia, Saunders College Publishing, 767 p.

Zelt, R.B., and Jordan, P.R., 1993, Waterquality assessment of the Central Nebraska Basins - Summary of data for recent conditions through 1990 : U.S. Geological Survey Open-File Report 93-422, 178 p.

\section{USGS FS-179-99}

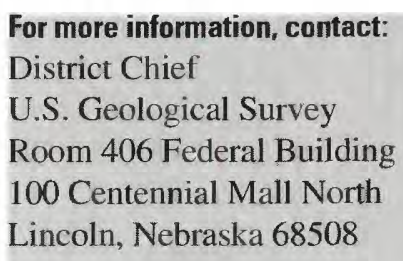

Information regarding the NAWQA Program is available on the Internet via the World Wide Web. You may connect to the NAWQA Home Page using the Universal Resource Locator (URL): http://water.usgs.gov/nawqa/ nawqa_home.html 